\title{
Sprogprøve fra Fjolde
}

(sendt i 1901 til mag. P. K. Thorsen).

Ved lærer L. P e t e r s e n, Allinge.

En Bu'nd har en Broer boen i den næst Sta, den vår Gårner ${ }^{1}$ ) å besår en herle Frogtgår full av høj å kostle Bảem. AE Bu'nd gik issen te Stas for å besøg ham å vunnert sæ myll yover æ Båem, der oll sto i sårren nett Rejer.

"Hør, min Broer", såu æ Gårner te ham, „æ vill skænk ${ }^{2}$ ) dæ den best Båem ur av min (Plantschol ${ }^{3}$ ), å den ska du å din Børen ha Glæe ${ }^{4}$ ) av«.

Deretter prålt") æ Gårner ar sin Svenn å vi'st. dem den Båem, den di skull græv ur. $A$ Bu'nd vur falle gla å lo 'en bær ur å sin A'ger.

Om annes Måren vår han ikk iens mæ sæ sjille, vor han vill pla'nt æ Båem hen, for han tænkt $\left.t^{\circ}\right)$ : "Planter æ 'en høst hen å æ Høj, så ær 'en ursætt for æ Væer, å den kostle Frogt blæser av, før 'en værr moen; å pla'nter æ 'en ve' $æ$ Vej, så kan novver, der gær forbi, lå Lost te di søe $A$ Ebel å sjæl 'em; å sætter

1) Udtales med hollandsk (plattysk) g.

2) Også udtalt sjænk.

") - schol udtales med hollandsk sch.

4) Ordet bruges nu sjældent; hyppigst siges "Froover".

") kaldte; Hjoldelund og mâske Jørl har »kåll«.

") Udtales med tydeligt $\mathrm{k}$. 
$æ$ 'en tæ't ve' æ Hus ve' æ Dør, så ær æ ikk se'ker for min een $\left.^{7}\right)$ Børen å for $æ$ Ti $(e)$ nester. Tesist sætt han æ Båem unner æ norr Si æbog æ Lae.

En Prik efter Selvlydstegnet betyder, at Selvlyden er lang ("Ager«, ikke "Agger«, som i Jörl og videre mod Øst (ng Nord).

Ved Marius Kristensen.

i: Cdtales i to Stavelser. 